\title{
カチオン性高分子を用いたインスリンの粘膜吸収促進
}

\author{
関俊暢
}

\section{Enhancement of Insulin Absorption through Mucosal Membranes Using Cationic Polymers}

\author{
Toshinobu SEKI \\ Faculty of Pharmaceutical Sciences, Josai University, 1-1 Keyakidai, Sakado, Saitama 350-0295, Japan
}

(Received May 21, 2010)

\begin{abstract}
Cationic polymers (e.g., cationated gelatins, cationated pullulans and poly-L-arginines) have potential to promote transmucosal delivery of peptide and protein drugs without producing any toxic effects on epithelial cells. These cationic polymers could interact with the mucosal membranes and increase the number of pathways for water-soluble macromolecules in the tight junctions. In the case of insulin having negative charges in neutral solutions, interaction between the cationic polymers and insulin is also important to promote suitable delivery. An appropriate interaction can help insulin to access to cell surface, but too strong interaction suppresses insulin absorption. When the absorption-enhancing effects of sperminated pullulans and gelatin having different numbers of amino groups on the pulmonary absorption of insulin in rats were evaluated, their enhancing effects correlated with the amino group content. Cationic polymers having suitable charge density will be useful for pulmonary delivery systems of insulin.
\end{abstract}

Key words_— insulin; cationic polymer; pulmonary delivery; tight junction; absorption enhancer

\section{1. はじめに}

インスリンなどのペプチド性医薬品は，その粘膜 透過性の低さと酵素分解抵抗性の低さから, 現在主 に注射剤として利用されている。しかし，患者への 負担を考えた場合，患者自身による服薬コントロー ルが容易な, 経口剂, 経鼻吸収剂, 経肺吸収剂など の粘膜適用製剤の開発が望まれる. ${ }^{1)}$ その達成のた めには，解決すべき多くの製剤学的問題が存在する が，特にある程度以上の分子量を有する医薬品では その粘膜透過性の改善が不可欠であり, 吸収促進の 方法の開発は意義深い。 ${ }^{2}$ 吸収促進剤としてのカチ オン性高分子は，水溶性高分子薬物の粘膜透過性 を，粘膜上皮細胞に傷害を与えることなく効果的に 促進することから，ペプチド性医薬品の製剤に用い る添加剤として注目されている，粘膜透過促進作用 を有するカチオン性高分子としては，キトサン及び その誘導体，ポリアルギニン，カチオン化ゼラチ ン，カチオン化プルランなどが知られており，その

城西大学薬学部（†350-0295 埼玉県坂戸市けやき台 1 $-1)$

e-mail: sekt1042@josai.ac.jp

本総説は, 日本薬学会第 129 年会シンポジウム S15 で 発表したものを中心に記述したものである.
作用機構として，上皮細胞間のタイトジャンクショ ンの開口作用が考えられている. ${ }^{3)}$ 細胞表面は負に 帯電しているため, カチオン性の高分子は静電気的 相互作用により細胞表面と相互作用し，細胞間の結 合を弱めるようなシグナルが生じる，その変化が可 逆的なもので，また細胞自身の機能に悪影響を及ぼ さなければ，ペプチド性医薬品の吸収改善を安全か つ有効に行うことができる。

本稿では，前半部で，上皮細胞間のタイトジャン クションの開口作用をカチオン性高分子の共通した 作用機構であると仮定し，その開口状態の定量的評 価について検討した結果を記述し，また後半部で は，インスリンのカチオン化ゼラチン及びプルラン による経肺吸収促進の機構について, タイトジャン クションの開口以外の作用も含めて検討した結果を 述べる. 最後にカチオン化高分子を吸収促進剂とし て含むインスリンの経肺吸収製剤を開発するために 残されている問題について考えを示す.

2. Renkin 式を用いたタイトジャンクション開 口状態の定量的評価

上皮細胞間のタイトジャンクションの開口作用が カチオン性高分子の吸収促進機構であることは, 多 くの論文で述べられているが，その開口の様式につ 


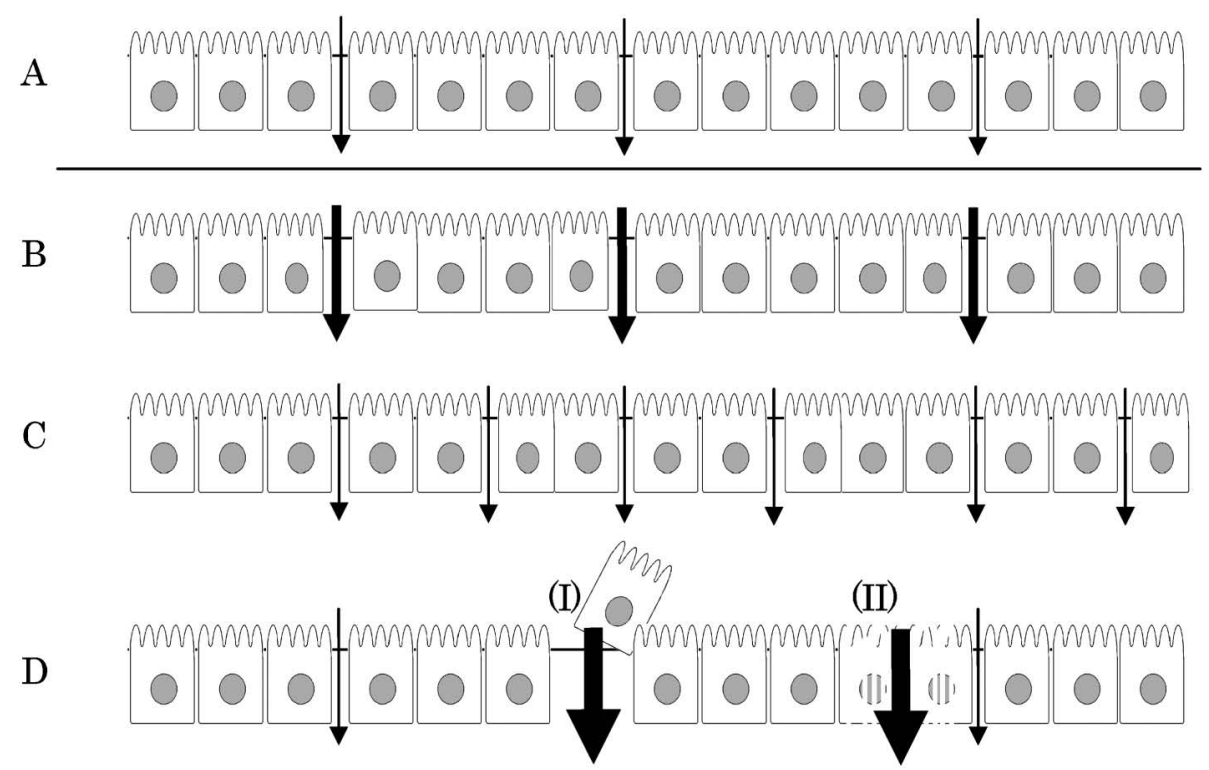

Fig. 1. Models of Permeation Routes for Water-soluble Large Molecules through Epithelial Cell Layers and the Effects of Penetration Enhancers on these Pathways

A: Normal conditions; a few paracellular pathways are "open" to allow the passage of relatively large molecules. B: Increase in size of the pathway produced by enhancers; the pathways increase in size and larger molecules are able to pass via these routes. C: Increase in the number of pathways by enhancers; the pathways increase and the permeability coefficient of each drug should be proportional to the number. D: Damage to epithelial cell layers by enhancers; undesirable changes in epithelial cell layers, such as emergence of cells (I) and complete loss of barrier functions of membranes (II) increase the permeability of all penetrants.

いては十分な議論がなされていない. Figure 1 は, 水溶性高分子化合物の上皮細胞層透過経路とその変 化のモデルを示している. ${ }^{4)}$ 分子量 $4 \mathrm{kDa}$ 程度の FITCでラベルされたデキストラン（FD4）を各種 粘膜に適用した場合，特殊な処理を施さなくてもわ ずかではあるが透過が観察される。このことから本 来は水溶性物質の透過バリアーであるタイトジャン クションを有する上皮細胞層でも，一部にそれらが 透過可能な部分（透過ルート）がコントロールの状 態でも存在することが考えられる [Fig. 1(A)]。 カ チオン性高分子やほかのいくつかの吸収促進剤は, タイトジャンクションを開口するが，その様式には 3 種考えられる。1 1 つ，コントロールの状態でも 存在する透過ルートの大きさがさらに開くような形 式で開口する様式で，この場合より大きい分子の透 過が可能となる [Fig. 1(B)]。2つ目は，通常の閉 じた状態のタイトジャンクションが，促進剤により 透過ルートに変化する場合で，個々の透過ルート自 体の大きさは変化しないがその数が増える場合であ る [Fig. 1(C)]。この様式では，薬物の透過係数は その透過ルートの数に比例することになるが，より 大きい分子が透過できるようになるわけではない. 最後は, 好ましくない変化であり, 細胞の脱落や脂

質二重膜のバリアー機能の完全な消失などにより, より大きな穴が生じる場合である [Fig. 1(D)]。こ のような変化を生じさせるような促進剤は，安全に 使用することはできない，B-Dのどの変化がカチ オン性高分子により生じているかを明らかにするこ とは，その安全かつ有効な使用と作用機構の解明に おいて非常に有意義であると考える.

Renkin 式 Eq. (1) は, 膜に存在する円柱状の透 過経路を介した輸送に係わる式であり，ある大きさ を有する薬物分子の膜透過性を，透過ルートへのア クセスのし易さとルート内での摩擦抵抗により説明 する. ${ }^{5)}$

$$
\begin{aligned}
F\left(\frac{r_{i}}{R}\right)= & \left(1-\left(\frac{r_{i}}{R}\right)\right)^{2}\left[1-2.104\left(\frac{r_{i}}{R}\right)\right. \\
& \left.+2.09\left(\frac{r_{i}}{R}\right)^{3}-0.95\left(\frac{r_{i}}{R}\right)^{5}\right]
\end{aligned}
$$

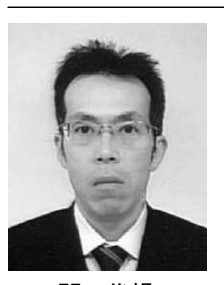

関 俊暢
城西大学薬学部薬品物理化学講座教 授. 薬学博士. 1987 年城西大学薬学研 究科中退. 1987 年 2002 年城西大学薬 学部薬剂学講座 (助手)。2002 年～2008 年北海道薬科大学薬剤学分野 (講師〜 准教授, 森本一洋教授の研究室) . 2005 年〜2006 年 ETH チューリッヒ薬学研 究所留学. 2008 年より現職. 
ここで, $r_{i}$ は透過する分子の半径， $R$ は透過ルー トの半径である。もし，分子の半径が透過ルートよ り十分に小さければ，この関数は 1 となり，膜透過 速度は単純に各分子の拡散係数と濃度勾配に依存す る. 一方, 分子の半径と透過ルートの半径が近い場 合，透過ルートへのアクセスは難しくなり，また内 部では大きな摩擦抵抗を受ける。この式が成立する 条件で, 薬物の膜透過係数 $\left(P_{A}\right)$ や透過クリアラ ンス $\left(C L_{A}\right)$ は, Eqs. (2), (3)のように表される.

$$
\begin{gathered}
P_{A}=(A / L) \cdot D_{i} \cdot F\left(\frac{r_{i}}{R}\right) \\
C L_{A}=\left(A^{\prime} / L\right) \cdot D_{i} \cdot F\left(\frac{r_{i}}{R}\right)
\end{gathered}
$$

ここで， $D_{i}$ は透過する分子の拡散係数， $L$ はバ リアーの厚さである。また， $A$ は膜表面で透過 ルートが占める面積分率であり，空隙率 $(\varepsilon)$ に等 しいのに対し， $A^{\prime}$ はそれに有効透過面積を掛けた 值で, 膜表面で透過ルートが占める総面積になる. 分子半径 $r_{i}$ は, Stokes-Einstein 半径として拡散係数 $D_{i}$ と関係づけることができるので $[\mathrm{Eq}$. (4) ],$A /$ $L$ 若しくは $A^{\prime} / L$ と $R$ の值が決まれば，ある拡散係 数を有する透過分子の透過係数若しくは透過クリア ランスが計算できる. ${ }^{6}$

$$
D_{i}=\frac{k_{B} \cdot T}{6 \cdot \pi \cdot \eta \cdot r_{i}}
$$

ここで， $k_{B}$ はボルツマン定数， $T$ は絶対温度， $\pi$ は円周率， $\eta$ は媒体の粘度である。 $A / L$ 若しくは $A^{\prime} / L$ と $R$ の值は, 拡散係数既知の 2 つの薬物の $P_{A}$ 若しくは $C L_{A}$ の測定により決定することができ る.

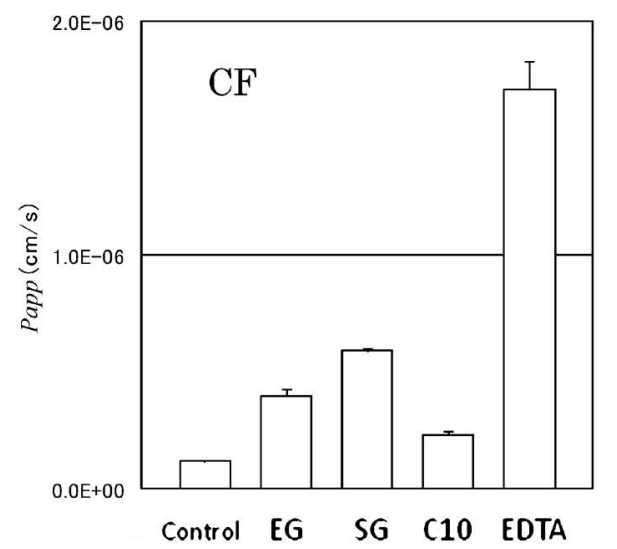

消化管粘膜のモデルである Caco-2 細胞単層膜を 用いて，カチオン化ゼラチンの細胞間隙透過経路へ の影響を評価した. ${ }^{4)}$ すなわち，エチレンジアミン 化ゼラチン (EG), スペルミン化ゼラチン (SG), 比較のためのカプリン酸 $(\mathrm{C} 10), \mathrm{EDTA}$ を $0.2 \%$ 含 む溶液を粘膜表面に作用させた場合の透過性の変化 を，カルボキシフルオレセイン $(\mathrm{CF}, D=5.87 \times$ $\left.10^{-6} \mathrm{~cm}^{2} / \mathrm{s}, r=0.56 \mathrm{~nm}\right)$ と FD4 $\left(D=2.39 \times 10^{-6}\right.$ $\left.\mathrm{cm}^{2} / \mathrm{s}, r=1.36 \mathrm{~nm}\right)$ を細胞間隙透過マーカーとし て同時適用し，奨膜側に透過した量を分離定量して それぞれの透過性を評価した．Figure 2 に両マー カー分子の透過係数 $P$ の変化を示す．いずれの添 加剂も両マーカー分子に対して促進作用を示した が，この条件では EDTA が最も高い効果を示し た。これらのデータを Renkin 式に当てはめること で， $A / L$ と $R$ の值が求まる. 得られた值を Fig. 3 に示す。最も高い透過促進作用を示した EDTA に おいて， $A / L$ と $R$ の值はともに増大しており, 細 胞の脱落などが生じていることが懸念された。また， $\mathrm{C} 10$ においては $R$ の増大が認められ，透過ルート 自体の変化が示唆された。 一方，カチオン化ゼラチ ンでは, $A / L$ の変化に比較して $R$ の変化はわずか であり，個々の透過ルートが大きくなることなく面 積が増える，すなわち透過ルートの数が増加してい ると考えられた [Fig. 1(C)]。通常の閉じたタイト ジャンクションの一部が，透過ルートへと変化した と考えられる。このような変化の場合，既にある程 度透過する薬物であれば，ルート数の増大に依存し て透過性が促進されるが，透過不能であったような 大きな分子が促進剤の処理により透過可能となると

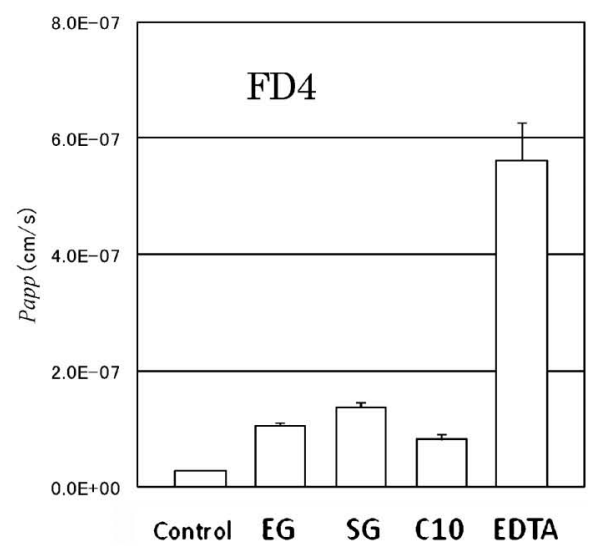

Fig. 2. Effect of Penetration Enhancers on the Permeability Coefficients of CF and FD4 through Caco-2 Cell Monolayers Each enhancer was applied as a $0.2 \%$ solution. 

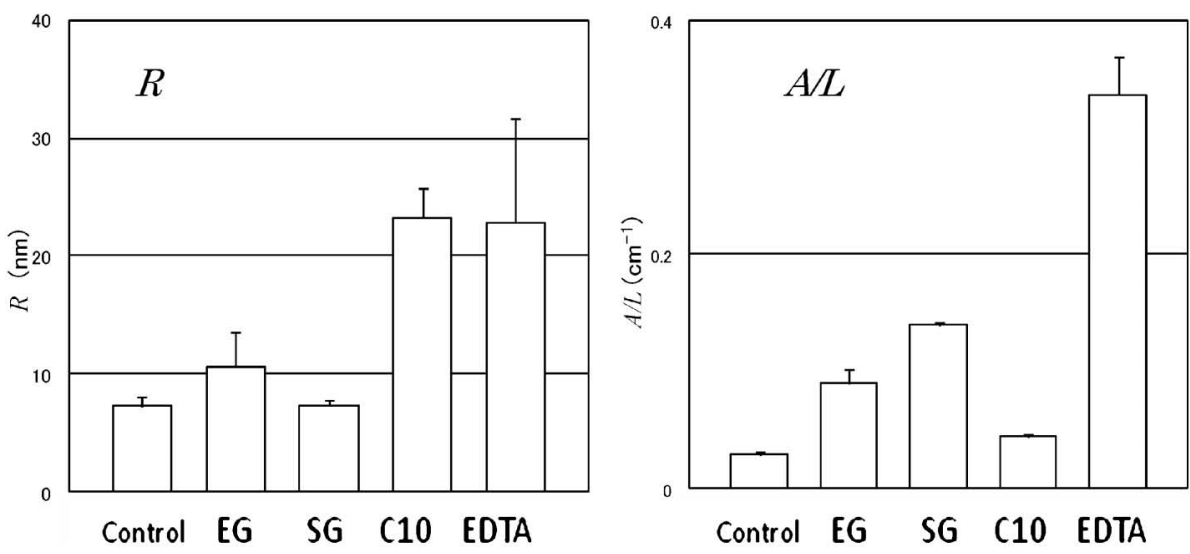

Fig. 3. Effects of Enhancers on the Values of $R$ and $A / L$ of Caco-2 Cell Monolayers Each enhancer was applied as a $0.2 \%$ solution.

いうような効果は期待できない。このことは，力チ オン化ゼラチンの限界を示すものであるが，別の見 方をすれば，促進剤がもたらす状況が，正常な生理 学的環境下での状況と大きく異なってはなく, 安全 性や可逆性という点では有利であることが期待でき る. 同様な in vitro における細胞間隙の変化は，気 道上皮のモデルである Calu-3 細胞単層膜において も観察されている. ${ }^{7)}$

これらのカチオン性高分子による細胞間隙透過性 の変化が in vivo でも観察されるかについて, 各種 分子量の FITC ラベルデキストラン（FD4, FD10, FD40, FD70）のラット鼻腔内投与後の吸収に及ぼ すポリ-L-アルギニン（pArg）の効果から検討し た. ${ }^{8)}$ すなわち，血中濃度推移からデコンボリュー ション計算により吸収速度を求め, 適用濃度との関 係から $C L_{A}$ を得た。 FD4 と FD40の $C L_{A}$ について Renkin 式に当てはめ， $A^{\prime} / L$ と $R$ の值を得るとと もに，それらの值を用いて拡散係数と $C L_{A}$ の関係 に関するシミュレーション曲線を作成し，FD10 と FD70 のデータがその直線上にプロットされること を確認した。 Renkin 式による解析の結果，pArg の 適用時には $R$ の值の増加なしに, $A^{\prime} / L$ が 30 倍以 上大きくなっていることが示され，pArgにおいて も，そして in vivo においても細胞間隙の透過経路 の数を増やすことで吸収の促進がなされていること が明らかになった。

3. インスリンのカチオン化ゼラチン及びカチオ ン化プルランによる経肺吸収促進

前項で述べたような機構がカチオン性高分子の吸 収促進機構であった場合, 各薬物の $P_{A}$ 若しくは
$C L_{A}$ の期待值は，その分子量のみに依存すること になる．しかし実際に，各種ペプチド性医薬品の粘 膜吸収促進を試みた場合，観察される值は期待值よ り低く，またその程度はぺプチド性医薬品の種類に よって異なる，例えば，われわれが行った予備検討 の結果では, pArg はカルシトニンには高い効果を 示すが，インスリンに対してはほとんど効果を示さ ない。一方， EG, SG，スペルミン化プルラン（SP) はインスリンの鼻粘膜吸収促進に効果が高く，逆に カルシトニンには効果が低い。ペプチド性医薬品は その等電点の違いにより中性溶液中での解離状態が 異なり，例えばカルシトニンは正の，インスリンは 負の電荷を有している．カチオン性高分子はインス リンのような負の荷電を有するぺプチドと相互作用 すると考えられるが，その程度はカチオン性高分子 の正電荷の密度に依存する。インスリンとカチオン 性高分子を粘膜上に適用する際，この静電気的相互 作用により濁りが観察されるが，この生じた粒子か らのインスリンの放出は, 電荷密度の高い pArg で は低く，SG, SP などでは高いことが明らかとなっ ている (未発表データ)。このことはインスリンの 吸収促進作用の両者間の違いに深く係わっていると 推察される。

肺の粘膜は，総面積が広く薬物透過性も高いた め, ペプチド性医薬品の適用部位として可能性が高 い. $\left.{ }^{9}\right)$ インスリンの経肺吸収製椷が開発されれば, 患者自身による投薬管理がより容易になり，コンプ ライアンスの改善が期待できる. カチオン性高分子 をその際の吸収促進剤として利用する場合，上述の 理由から SG やSP が有望である。そこで，ラット 


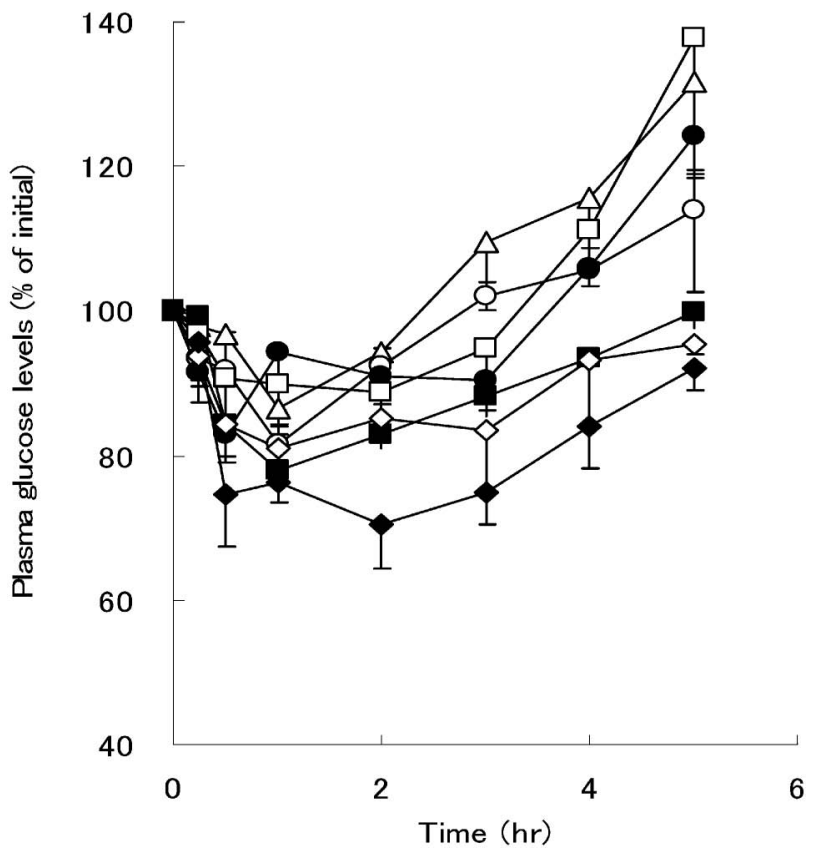

Fig. 4. Effect of Sperminated Polymers on the Glucose Levels in Plasma after Pulmonary Administration of Insulin in Rats Control (PBS), $\triangle$; insulin $(10 \mathrm{IU} / \mathrm{kg})$ alone, $\bigcirc$; insulin $(10 \mathrm{IU} / \mathrm{kg})$ with NP $0.1 \%, \square$; insulin $(10 \mathrm{IU} / \mathrm{kg})$ with NG $0.1 \%$, $\mathrm{kg})$ with SG $0.1 \%, \mathbf{\square}$; insulin $(10 \mathrm{IU} / \mathrm{kg})$ with $\mathrm{SP}-\mathrm{L} 0.1 \%, \diamond$; insulin $(10$ $\mathrm{IU} / \mathrm{kg}$ ) with SP-H $0.1 \%$,

を用いてインスリンの経肺吸収に及ぼす SG 及び SP の効果を検討した. ${ }^{10)}$ すなわち，インスリン 10 $\mathrm{IU} / \mathrm{kg}$ を MicroSprayer ${ }^{\circledR}$ を用いて気管深部から肺に 向かって投与し，その後の血中グルコース濃度の推 移を吸収促進剂の有無において比較した。その結果 を Fig. 4 に示す．SG 若しくは SP（低スペルミン 化プルラン, SP-L 若しくは，高スペルミン化プル ラン，SP-H）を $0.1 \%$ 含む系は，促進剤を含まない 系やカチオン化していないゼラチンやプルラン（そ れぞれ NG 及びNP）を含む系と比較して，血糖低 下作用が強く，かつ持続している。 またこの SGや SP の効果は，試験した範囲においては導入した陽 電荷が多い場合に促進作用が強いことが，スペルミ ン導入量が多い SP-H と導入量が少ない SP-L の比 較から示唆された。投与 5 時間後において，肺胞内 を洗浄し，その回収液中の乳酸脱水素酵素（LDH） の漏出を比較したところ，ポジティブコントロール である界面活性剂 Triton-X 100 や夕ウロコール酸 ナトリウムなどと比較して, LDH の漏出量は低 く，組織障害性も低いことが示された。

このインスリンの経肺吸収に対する SG や SP の 効果は，前項で述べた上皮細胞間のタイトジャンク
ションの開口作用によると考えられるが，それ以外 の作用についても検討する必要がある。すなおち, インスリンの分解過程における酵素的分解の抑制作 用，インスリンの粘膜表面における濃縮作用，イン スリンの会合状態の修飾作用などである，先に述べ たように，インスリン吸収に対する SG や SP の効 果は pArg と比較して強いが，この違いがインスリ ンとカチオン性高分子により形成される粒子からの その放出性の違いだけではなく，ここに示すような 吸収促進作用に係わるその他の作用の違いに関係し ていることも十分考えられる.

前項に示した Renkin 式による解析の結果を利用 し，インスリンの透過係数の期待值を計算すること ができ，その值と実測の透過係数の比較から透過過 程における分解の程度を推察できる. ${ }^{4)}$ すなわち,

Fig. 3 に示したような $A / L$ と $R$ の值に基づき, 拡 散係数 $D$ と透過係数 $P$ の関係のシミュレーション カーブを描き，別にインスリンの $D$ の測定を行っ て，Pの值を予測する。そして，実測の $P$ と予測 值の比が粘膜透過過程における分解により規定され ていると考える，溶液中で会合性を示さないような ペプチド性医薬品では, 分子量の值から $D$ の值を 計算し，Pの期待值を得ることも可能であるが，个 ンスリンの場合, 中性溶液では主に 6 量体として存 在しているため，Dの実測值が必要となる．Figure 5 は, Calu-3 細胞単層膜における $D$ と $P$ の関係の シミュレーションカーブである. ${ }^{7)}$ インスリンの $D$ の実測值は $1.14 \times 10^{-6} \mathrm{~cm}^{2} / \mathrm{s}$ であり，この值から インスリンの $P$ の期待值が得られる. Table 1 には,

Fig. 5 の計算に用いたパラメータとインスリンの $P$ の実測值と予測值を，促進剂である SG $(0.2 \%)$ の 有無で比較して示した。インスリンの $P$ の実測值 は，その $D$ から予測される值の $1 / 10$ 以下であり， 透過過程における分解などによって透過性が低下し ていることが示された. SG 共存下においてもその 傾向は変化せず，SG には透過過程におけるインス リンの分解を抑制する効果を期待できない.

カチオン性である SG や SP は，アニオン化して いるインスリンと前述のように相互作用すると考え られるが，粘膜上に適用した場合には，その表面に 存在する陰電荷との相互作用, すなわち, 促進剤一 インスリンー細胞表面の 3 者間の相互作用について 考える必要がある，そこで，赤血球をモデル細胞と 


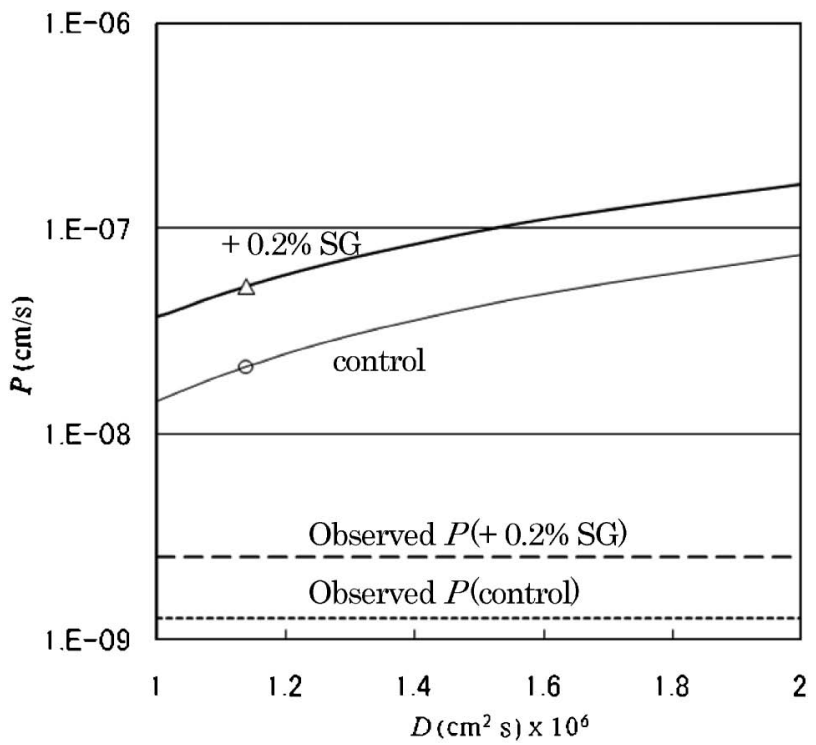

Fig. 5. Relationship between $D$ of Penetrants and the $P$ through Calu-3 Cell Monolayers, and the Calculated $(O$, $\triangle$ ) and Observed (---, ---) $P$ of Insulin

Table 1. Parameters of Calu-3 Cell Monolayers, and the Calculated and Observed $P$ of Insulin through the Layers

\begin{tabular}{ccccc}
\hline \hline & $\begin{array}{c}A / L \\
\left(\mathrm{~cm}^{-1}\right)\end{array}$ & $\begin{array}{c}R \\
(\mathrm{~nm})\end{array}$ & $\begin{array}{c}\text { Calculated } P \\
(\mathrm{~cm} / \mathrm{s}) \times 10^{8}\end{array}$ & $\begin{array}{c}\text { Observed } P \\
(\mathrm{~cm} / \mathrm{s}) \times 10^{9}\end{array}$ \\
\hline \multirow{2}{*}{ Control } & $\begin{array}{l}0.0775 \\
\pm 0.0143\end{array}$ & $\begin{array}{l}10.4 \\
\pm 4.2\end{array}$ & 2.13 & $1.28 \pm 0.92$ \\
$+0.2 \% \mathrm{SG}$ & $\begin{array}{l}0.157 \\
\pm 0.042\end{array}$ & $\begin{array}{l}11.7 \\
\pm 3.1\end{array}$ & 5.25 & $2.89 \pm 2.74$ \\
\hline \multicolumn{5}{c}{} \\
\end{tabular}

して，この 3 者間の相互作用をゼータポテンシャル の測定により評価した. ${ }^{10)}$ その結果を Fig. 6 に示 す。赤血球自身は負に帯電しているが，それに SP を処理すると赤血球表面に SP が結合してゼータポ テンシャルは正を示す。一方，赤血球にインスリン を共存させてもゼータポテンシャルはほとんど変化 しないが，SP を処理した赤血球ではそのゼータポ テンシャルはほとんど消失する。これは, 赤血球表 面に結合した SP に，さらにインスリンが結合した ことによると考えられる。同様な相互作用が粘膜表 面でも生じれば，粘膜の表面近傍にインスリンが高 濃度に濃縮され，そのことが吸収の促進に一部寄与 することも考えられる．比較のために行った正電荷 を有するカルシトニンでは, カルシトニン自身の赤 血球膜への相互作用が推察されるものの，SP の効 果は示されていない.

インスリンは中性溶液中で主に 6 量体として存在

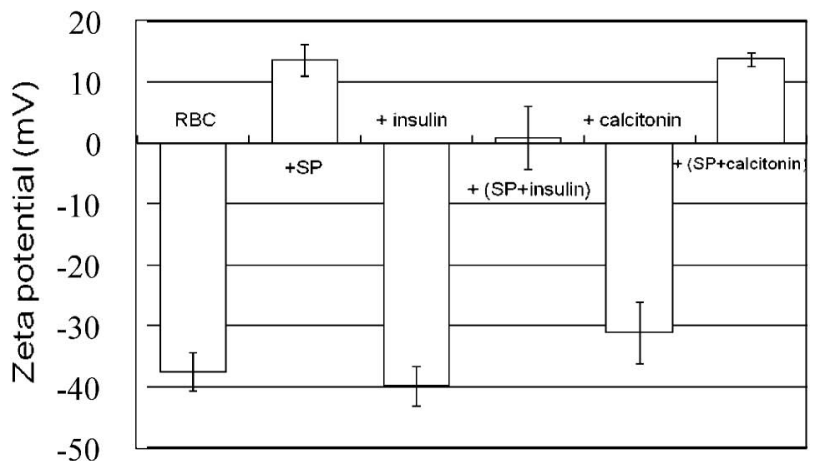

Fig. 6. Effect of Insulin, Calcitonin and SP on the Zeta Potential of Red Blood Cell (RBC)

しているので，それを 2 量体や単量体にすることが できれば，そのことだけでも透過の促進が期待でき る. SG や SP をインスリンと共投与するとき，一 時的に凝集体を形成するが，透過自体はそこから放 出されたインスリンにより生じると考えられ，その 際のインスリンの会合状態についても検討か必要で ある.これまでの検討で, 酸性で溶解させたインス リン溶液を中和する際に SP を共存させると， 2 量 体が生じ易くなることを示唆する結果が動的光散乱 測定により示されているが（未発表データ），ほか の測定技術により同じ現象を確認するまでには至つ ていない，更なる検討が必要と考えている。

\section{4. インスリンの経肺吸収製剤を開発するために}

カチオン化高分子を吸収促進剤として含むインス リンの経肺吸収製剂を開発するためには，解決しな ければならない課題は多い。ある種のカチオン性高 分子は遺伝子治療やワクチン開発を目的とした細胞 内への物質の送達にも利用させており, カチオン性 吸収促進剂自身やそれに付随したほかの成分の上皮 細胞内への移動とそれに伴い生じる細胞の生理機能 変化についてはさらに詳細に検討する必要があ る. ${ }^{11)}$ その変化のいくつかは，直接的若しくは間接 的に，カチオン性高分子促進剂による細胞間隙開口 に係わることも考えられるが，副作用として好まし くない反応を引き起こす可能性についても十分調査 しなければならない。 また，タイトジャンクション 開口の可逆性についても, 安全性との係わりから評 価が必要である.

負電荷を有するインスリンはカチオン性高分子と 相互作用して粒子を形成するが，実際に投与された 生体中で，どのようにその粒子からインスリン及び 
促進剤が放出するのかについて更なる検討が必要で ある．特に経肺投与製剂では，投与薬物の粒子径が 肺胞組織への薬物送達効率に深く係わるので, 適切 な粒子径を有し，かつ確実な吸収促進効果とインス リン放出が得られるように製剤を処方設計し，その 調製法を確立するためには多くの努力が必要になる と予想される.

\section{5. まとめ}

カチオン性高分子は，粘膜上皮細胞に障害を与え ることなく，ペプチド性医薬品の吸収を促進する添 加剤として有望である。その機構は，主に細胞間隙 のタイトジャンクションの開口であるが，促進剤一 薬物一細胞表面の 3 者間の相互作用も吸収の過程に 係わっており，その程度を最適に制御することも有 効な製剂設計において重要であろう。特にインスリ ンの経肺吸収の促進においては，SG と SP は pArg よりその点で優れており，粒子径の制御と安全性に 関する十分な検証がなされれば，その実用化が期待 できる

謝辞本研究は, 北海道薬科大学並びに城西大 学薬学部においてなされたものであり, ご指導賜つ た北海道薬科大学森本一洋教授, 城西大学薬学部森 本雍憲教授, 從二和彦教授, 夏目秀視教授に感謝の 意を表します。また，有益なご助言を賜った城西大 学薬学部大竹一男助教に感謝いたします。さらに研 究にご協力頂いた研究室のスタッフ・大学院生諸氏 にお礼申し上げます。

\section{REFERENCES}

1) Wearley L. L., Crit. Rev. Ther. Drug Carrier Syst., 8, 331-394 (1991).

2) Davis S. S., Illum L., Clin. Pharmacokinet., 42, 1107-1128 (2003).

3) Natsume H., Iwata S., Ohtake K., Miyamoto M., Yamaguchi M., Hosoya K., Kobayashi D., Sugibayashi K., Morimoto Y., Int. J. Pharm., 185, 1-12 (1999).

4) Seki T., Kanbayashi H., Nagao T., Chono S., Tabata Y., Morimoto K., J. Pharm. Sci., 95, 1393-1401 (2006).

5) Renkin E. M., J. Gen. Physiol., 38, 225-243 (1954).

6) Seki T., Harada S., Hosoya O., Morimoto K., Juni K., Biol. Pharm. Bull., 31, 163-166 (2008).

7) Seki T., Kanbayashi H., Chono S., Tabata Y., Morimoto K., Int. J. Pharm., 338, 213-218 (2007)

8) Seki T., Hosaya O., Natsume H., Sato I., Egawa Y., Nakagawa H., Juni K., Morimoto Y., J. Drug Delivery Sci. Technol. 19, 331-335 (2009)

9) Gonda I., J. Aerosol Med., 19, 47-53 (2006).

10) Seki T., Fukushi N., Chono S., Morimoto K., J. Control. Release, 125, 246-251 (2008).

11) Ohtake K., Maeno T., Ueda H., Natsume H., Morimoto Y., Pharm. Res., 20, 153-160 (2003). 